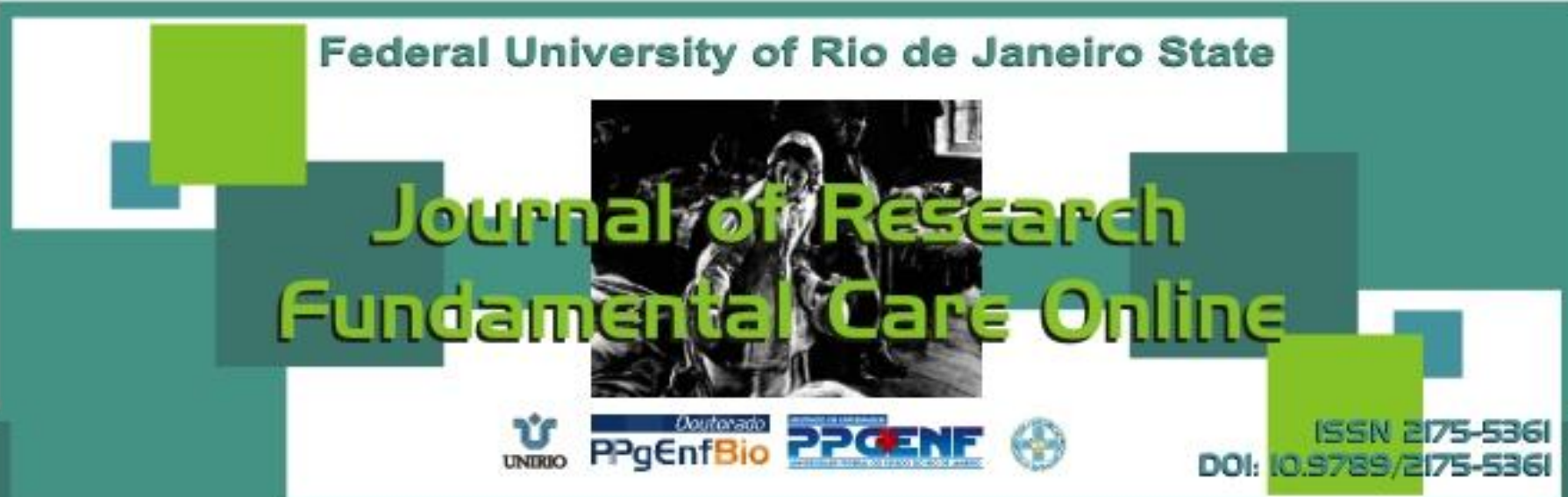

\title{
RESEARCH
}

\section{Falls in elderly: identification of extrinsic risk factors at home}

Quedas de idosos: identificação de fatores de risco extrínsecos em domicílios

Las caídas de los ancianos: la identificación de factores de riesgo extrínsecos en la vivienda

Caio Drummond de Amorim Bizerra ${ }^{1}$, Rogério Fabiano Gonçalves ${ }^{2}$, Amanda de Figueirôa Silva Carmo $^{3}$, Rodrigo Nonato Coelho Mendes ${ }^{4}$, Laísla Alves Moura ${ }^{5}$

ABSTRACT

Objective: To identify extrinsic risk factors those predispose the occurrence of falls in the elderly at home. Method: A total of 95 homes about the presence of risk factors, using a structured interview. Results: From 95 of the residences valued only 7.4\% (7) had no mismatches according to the items assessed. it was observed that mismatches involving carpets and buffers were the most prevalent, together accounting for approximately $40 \%$ of the problems identified in the search. other relevant problems were related to the lack of grab bars in places that required its use, switches arranged in hard to reach places and away from the entrance of the rooms in the home, floors with changes in its topography, poor illuminated environments and furniture obstructing the passage of the elderly. Conclusion: The risk factors for falls were present in most homes, and most of these are preventable factors. Descriptors: Accidental falls, Risk factors, External causes, Aged, Nursing.

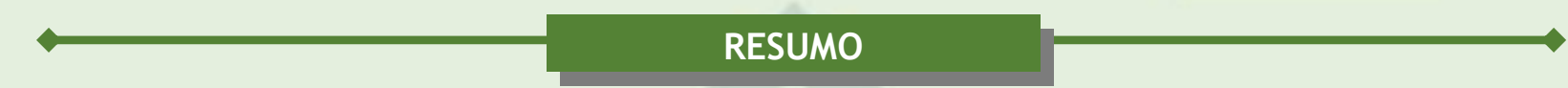

Objetivo: Identificar fatores de risco extrínsecos que predispõem a ocorrência de quedas de idosos em ambiente domiciliar. Método: Foram avaliadas 95 residências quanto à presença de fatores de risco, utilizando-se entrevista estruturada. Resultados: Das 95 residências avaliadas apenas 7,4\% (7) não apresentaram inadequações de acordo com os itens avaliados. Observou-se que as inadequações envolvendo tapetes e batentes foram as mais prevalentes, representando em conjunto cerca de $40 \%$ dos problemas identificados na pesquisa. Outros problemas relevantes foram relativos à ausência de barras de apoio em locais que requeriam o seu uso, interruptores dispostos em locais de difícil acesso e longe da entrada dos cômodos do domicílio, pisos com alterações no seu relevo, iluminação insuficiente nos ambientes e móveis obstruindo a passagem do idoso. Conclusão: os fatores de risco para quedas estiveram presentes na maioria das residências, sendo que boa parte destes são fatores preveníveis. Descritores: Acidentes por quedas, Fatores de risco, Causas externas, Idoso, Enfermagem.

\begin{abstract}
RESUMEN
Objetivo: Identificar los factores de riesgo extrínsecos que predisponen a la ocurrencia de caídas en los ancianos. Método: un total de 95 viviendas fueran avaluadas cuanto a la presencia de factores de riesgo, utilizando entrevista estructurada. Resultados: De las 95 residencias valoradas sólo el 7,4\% (7) no tenía desajustes de acuerdo con los ítems evaluados. Se observó que los desajustes relacionados con alfombras y amortiguadores fueron los más frecuentes, que en conjunto representan aproximadamente el $40 \%$ de los problemas identificados en la búsqueda. otros problemas relevantes estuvieron relacionados con la falta de barras de apoyo en los lugares que requieren su uso, interruptores dispuestos en lugares de difícil acceso y lejos de la entrada de las habitaciones de la casa, pisos con cambios en su topografía, pobre iluminación en ambientes y muebles bloqueando el paso de los ancianos. Conclusión: Los factores de riesgo para las caídas estuvieron presentes en la mayoría de los hogares, y la mayoría de estos son factores evitables. Descriptores: Accidentes por caídas, Factores de riesgo, Causas externas, Anciano, Enfermería.
\end{abstract}

${ }^{1}$ Physioterapist. Degree in physical therapy from the University of Pernambuco, Brazil. E-mail: caiodrummond1@hotmail.com. ${ }^{2}$ Physiotherapist. Graduated from the Federal University of Pernambuco - UFPE. Master in Public Health also UFPE. Assistant professor at the University of Pernambuco-UPE. Brazil. E-mail: caodrummond1@hotmail.com. ${ }^{3}$ Registered Nurse. Master in maternal and child health at the Institute of Integrative Medicine of Pernambuco - iMIP. Member of the Study Group on Critical Care - GECC. E-mail: amandafigueiroa@gmail.com. ${ }^{4}$ Registered Nurse. Degree in nursing by the Federal University of San Francisco Valley. Resident in Nursing Services Management by the University Hospital of Londrina/State University of Londrina, Brazil. Email: laislaalves19@gmail.com. ${ }^{5}$ Registered Nurse. Degree in nursing by the Federal University of San Francisco Valley. E-mail: rodrigo.coelho.mendes@gmail.com. 


\section{INTRODUCTION}

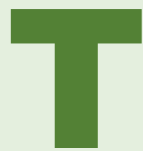

he elderly population in Brazil in 2010 was about 20 million inhabitants, which already represented a ratio of $10,8 \%$ compared to other age groups. ${ }^{1}$ This growing proportion of elderly motivates the discussion on issues related to health and quality of life for this age group. One of the topics of interest to public health has been the occurrence of falls in the elderly and the health consequences resulting from this condition, encouraging the scientific understanding of the causes and ways to achieve effective prevention. According to the World Health Organization (2007) about 28\% to $35 \%$ of people aged over 65 years fall each year, and this proportion increases from $32 \%$ to $42 \%$ for the elderly over the age of 70 years old. ${ }^{2}$

It points out that the falls are a major cause of morbidity, mortality and disabilities among the elderly. In the study, followed up for two years 1.944 seniors hospitalized for hip fracture occurrence and reported a mortality rate during hospitalization of $4 \%$, rising in four months and to $16 \%$ in 24 months to $38 \%$, showing the high mortality rate for hip fractures among elderly..$^{3-4}$

Thus, the causes that influence the occurrence of falls in the elderly are multiple, consisting of risk factors intrinsic and extrinsic. In general, the intrinsic factors include physiological changes of aging, pathological conditions and reactions to the use of drugs, being reported in this category causes the presence of muscle weakness, impaired balance and coordination body, visual impairment, deterioration cognitive, among others. Among the extrinsic factors cited were environmental hazards (slippery floors, obstacles on the floor of the yard, open staircase, among others), social situations of risk, use of footwear and accessories mobility inadequate or used incorrectly. ${ }^{5-8}$

The home is a space that can influence the well-being of the elderly, and the safety and comfort in the home essential requirements, since people in this age group (60 or older) typically spend $60-70 \%$ of their time in house. In 2008 , to investigate the influence of falls on quality of life of 37 elderly, a survey revealed that about $60 \%$ of falls occurred at home and $40 \%$ of cases outside the residence. ${ }^{6}$ Overall, $88,5 \%$ of the elderly began to feel fear of falling after the incident, $26,9 \%$ left the activity that caused the fall and $23,1 \%$ changed habits, routine situations that reveal the fear of falling again and demonstrate the insecurity of these people in the home. ${ }^{6,9}$

Still, the determinant risk factors for falls in the home and outside are different, requiring specific prevention strategies when considering the place of occurrence. Therefore, it is considered that most falls occur in the very elderly housing and that most studies on the determination of risk factors for falls leave the outcome to exposure after the occurrence of the disorder ${ }^{(10)}$. Thus, the study aimed to identify extrinsic risk factors that predispose to the occurrence of falls in the elderly in the home environment. 


\section{METHODOLOGY}

This is a descriptive, cross-sectional, exploratory, quantitative approach. We opted for the type of study due to the limited knowledge accumulated and systematized, and was developed in the neighborhood Vila Eduardo in Petrolina-PE. ${ }^{11}$

In total, 240 houses were visited (10\% of households in the district and $30 \%$ of households in selected sectors) by systematic criterion of visits, households were randomly selected. Of these, 95 were evaluated for the presence of risk factors, using a checklist of their own creation, with the inclusion criterion households in which elderly and resided there consent for the research. It was expected that at least 60 houses (25\% of the sample) met the requirements proposed. Given the house holds visited this number was exceeded.

This checklist has been prepared in order to verify in each room of the home (elderly's bedroom, living room, bathroom, kitchen, etc.), The presence of risk factors more common in the literature, allowing the registration of those observed during visits and reported by residents, which were not included in the instrument check.

The preparation process of data collection had the team training college students from health to identify the factors mentioned. Data were analyzed by descriptive method of proportions obtained from not being performed association tests due to escape the scope of the design chosen for the study. The study was approved by the Ethics and Research of the University of Pernambuco under registration CEP/UPE: 102/11 (CAAE: 0084.0.097.000-11), and respected the anonymity and the free will of the subject, thus respecting the resolution 196/96 National Health. ${ }^{12}$

\section{RESULTS AND DISCUSSION}

It was possible to identify which of the 95 homes evaluated, only $7.4 \%$ (7) had no mismatches according to the items assessed. Table 1 represents the observed environment and the relationship of the items classified as inadequate.

Table 1 - Frequency of the main risk factors for falls according to the spaces of the home assessed, Petrolina, PE, 2011.

\begin{tabular}{llcc}
\hline Room or space of residence & Item & $\begin{array}{l}\mathbf{N}^{\circ} \text { of inadequate (Total } \\
\text { evaluated) }\end{array}$ & of inadequate \\
\hline Externalarea & Door stop & $44(87)$ & $54,6 \%$ \\
& Floor & $30(87)$ & $34,5 \%$ \\
Room & Door stop & $26(93)$ & $27,9 \%$ \\
\hline
\end{tabular}




\begin{tabular}{|c|c|c|c|}
\hline & Carpet & $21(93)$ & $22,6 \%$ \\
\hline \multirow[t]{3}{*}{ Hall } & Handrail & $18(18)$ & $100,0 \%$ \\
\hline & (absence) & & \\
\hline & Lighting & $9(18)$ & $50,0 \%$ \\
\hline \multirow[t]{2}{*}{ Elderlyroom } & Carpet & $16(91)$ & $17,6 \%$ \\
\hline & Furniture & $16(91)$ & $17,6 \%$ \\
\hline \multirow[t]{3}{*}{ Elderlybathroom } & Support bar (absence) & $93(95)$ & $97,9 \%$ \\
\hline & Anti-slip mat (absence) & & \\
\hline & & $83(95)$ & $87,4 \%$ \\
\hline \multirow[t]{2}{*}{ Kitchen } & Switch & $27(92)$ & $29,3 \%$ \\
\hline & Furniture & $16(92)$ & $17,4 \%$ \\
\hline \multirow[t]{2}{*}{ Service area } & Door stop & $34(78)$ & $43,6 \%$ \\
\hline & Switch & $18(78)$ & $23,1 \%$ \\
\hline \multirow[t]{2}{*}{ Ladder orramp } & Handrail & $9(11)$ & $81,8 \%$ \\
\hline & *Floorandcarpet & $3(11)$ & $27,3 \%$ \\
\hline
\end{tabular}

* The percentageswereidentical.

Of the 87 households with outdoor area, 54.6\% (44) of access to this area had stops and $34.5 \%$ (30) of the floors were inappropriate situations justified by the presence of uneven, slippery or changes in its relief.

With regard to the environment of the rooms, $27,9 \%$ (26) had stops to your access and $22,6 \%$ (21) slippery rugs or poorly fixed. Considering the presence of hallway inside the households, only 18 possessed, these had not handrails or grab bars, 50\% (9) the lighting was poor or absent.

The observation, in each house, the room in which the elderly slept has highlighted as major risk factors the presence of carpets, mostly with sliding or folding the ends, and the presence of furniture with sharp corners, and the obstruction of passage, both with $17,6 \%(16)$ of occurrences, thus interpreted as inadequate.

Assessing the bathroom that the senior most used in every household, it was found that the inadequacies were the most frequent absences handrail (handrail) with a percentage of $97,9 \%(93)$ and the non-slip mat with $87,4 \%(83)$. Other items had an index of inadequacy smaller but relevant, as the presence of stop - 35,8\% (34), access door handle broken or rounded $-30,5 \%$ (29) and slippery or uneven - $28,4 \%(27)$.

In the evaluation of the environment of the kitchens were inadequate with percentage of $29,3 \%$ (27) switches/sockets, due to poor location (arranged in high places or far from the inlet port) and $17,4 \%$ (16) furniture, as obstructed locomotion or the elderly were high and required the use of stairs or banks to access food or household items.

With respect to service areas, $43,6 \%$ (34) were the inadequacies concerning the existence hinged on access, other irregularity constant was the poor location of switches and sockets, $23,1 \%(18)$.

In $81,8 \%$ (9) of households with stairs/ramp railing and there was $27,3 \%$ (3) of the floors, there were problems in relief and grip - slippery. It should be noted that in three homes $(27,3 \%)$ observed the presence of carpets or close to the ramp and steps were not observed the presence of slip tracks or signaling in homes, $100 \%$ (11). 
Table 2 is a summary of the items that had inadequacies in households for all environments, and for each item the table shows the two areas most relevant to the problem. In this sense, it is observed that for problems with the floor, the area outside the residence of the elderly and the bathroom were both spaces with greater frequency irregularities. Most of these percentages already described in Table 1 , but the analysis of Table 2 allows a differentiated.

Table 2 - Description of the most relevant physical spaces in the home in relation to item with inadequacies, Petrolina, PE, 2011.

\begin{tabular}{|c|c|c|}
\hline Item & Room & Percentage \\
\hline \multirow[t]{2}{*}{ Floor } & External area Bathroom for & $34,5 \%$ \\
\hline & the elderly & $28,4 \%$ \\
\hline \multirow[t]{2}{*}{ Lighting } & Hall & $50,0 \%$ \\
\hline & External area & $21,8 \%$ \\
\hline \multirow[t]{2}{*}{ Door stop } & Externalarea & $54,6 \%$ \\
\hline & Service area & $43,6 \%$ \\
\hline \multirow[t]{2}{*}{ Carpet } & Bathroom for the elderly & $87,4 \%$ \\
\hline & & $27,3 \%$ \\
\hline Switch & Kitchen & $29,3 \%$ \\
\hline Handrail or support bar & Hall & $100,0 \%$ \\
\hline \multirow[t]{2}{*}{ (absence) } & Bathroom for the elderly & $97,9 \%$ \\
\hline & Room of the elderly Kitchen & \\
\hline \multirow[t]{2}{*}{ Furniture } & & $17,6 \%$ \\
\hline & & $17,4 \%$ \\
\hline
\end{tabular}

Table 3 shows the quantitative risk factors identified in the households by main items that showed inadequacies, covering all evaluated environments. One can check that the inadequacies involving carpets and stops were the most prevalent, with about $40 \%$ of the problems identified in the survey.

Table 3 - Frequency of risk factors for falls identified according to the household items, Petrolina, Pernambuco, 2011.

\begin{tabular}{|c|c|c|c|}
\hline Item & & $\mathrm{N}^{\circ}$ of risk factors identified & Percentage \\
\hline Carpet & & 146 & $20,4 \%$ \\
\hline Door stop & & 145 & $20,2 \%$ \\
\hline $\begin{array}{l}\text { Handrail or } \\
\text { (absence) }\end{array}$ & support bar & 120 & $16,7 \%$ \\
\hline Floor & & 103 & $14,4 \%$ \\
\hline Switch & & 85 & $11,9 \%$ \\
\hline Furniture & & 60 & $8,4 \%$ \\
\hline Lighting & & 58 & $8,1 \%$ \\
\hline Total & & 717 & $100 \%$ \\
\hline
\end{tabular}


The occurrence of falls in the elderly is a common fact, which may be due to intrinsic or extrinsic causes, whether singly or in combination, involving, in general, more than one factor. In the home environment, this study showed that there were few households that had no extrinsic risk factors for falls.

This finding may indicate that there is little or no planning, either infrastructure or organization of physical spaces of the home and their constituents, to make the house a safer environment for the elderly. On the other hand, even if that concern exists, the purchasing power limits the options to make the home a safer environment to falls, unless the necessary changes do not involve high cost, but creativity, common sense, attention and willingness to care, modify or adapt the house according to the needs. ${ }^{3,6,13}$

Most studies on the subject have researched how to approach the central subject who suffered a fall and the health consequences and their effect on quality of life after injury. ${ }^{13-5}$ Others seek to understand the determinants of the fall from its occurrence, but there are few studies in the literature that evaluate such factors in the community, especially extrinsic causes or where the accident has not yet occurred. . $^{6,9,16-20}$

Considering the evaluation of the home environment, studies in long-stay institutions reveal that the room of the elderly is one of the environments in which falls occur more often between $23 \%$ and $43 \%$, but the reasons were not related to the event object of these studies. In this research the main inappropriate items in the room of the elderly were the presence of folds or carpets with little grip to the ground and furniture obstructing the passage. $^{7,21-2}$

Also, the bathroom was another area pointed by the authors above as area of high prevalence of falls, reaching $33.3 \%$ in one study. According to the data of this study, the presence of slippery surfaces, absence of anti-slip mats and grab bars are elements that may contribute to the high percentage quoted. ${ }^{7}$

However, in the investigated community - based on the situation within the housing and in the arguments of the residents - most of the elderly population is economically disadvantaged, lacking resources to put anti-slip flooring, carpets and adequate fixed support bars placed at strategic locations in order to minimize the incidence of falls. These can be evaluated as alternatives to more comprehensive reforms and cost. It is suggested that future studies that seek to involve the thematic work the social and economic characteristics in the data collection instrument.

One study found that the corridor is the third location of the house where the elderly most falls. How is a physical part of the house that has as main feature connecting one room to another, serving as access to other rooms, the need for frequent access the same can justify the importance of this as a place of falls. In this study we verified the absence of handrails and adequate lighting. ${ }^{21}$

In relation to items identified with a higher frequency of irregularities, the carpets had a higher prevalence, corroborating evidence from other studies that showed percentages around 49\%. Note that these studies indicate high prevalence of problems related to floors, revealing percentage of mismatch between $70,6 \%$ and $45 \%$ respectively, contradictorily with the present study found that inadequacies in $14,4 \% .^{7-10}$

The difference between the data may have been due to the method of analysis, since each household with inadequate space the floor would have relevance in the series of 
problems, not being home as rated by others, but for space rated. Another reason for this discrepancy may be the fact that the study had the highest percentage was performed in a low-income community in Rio de Janeiro, with serious infrastructure problems, is considered a risk area for housing, which imply differences on the characteristics of the communities investigated. ${ }^{6,23}$

Regarding access stops in the residence, the relevance of the problem in this study enters into an agreement with a survey to evaluate the item as one of the most unsuitable present in the residence. The absence of a handrail or handrail in the bathroom, ramps and ladders, was a concern identified in this study, since they are fundamental to aid the support of the elderly, especially those who have physical limitations, emphasizing that the premises usually identified as areas of high incidence of falls. ${ }^{6,22}$

A fact worth mentioning is the ignorance of the majority or older in the households visited residents about the risk factors for falls, this impression is confirmed by the study that shows that only the elderly who had suffered falls could identify such risks, which reveals the low importance given by the community investigated the factors mentioned. ${ }^{23}$

\section{CONCLUSION}

Risk factors for falls were present in most homes, denoting the potential that this type of injury has to happen. Preventive measures are necessary reasonable, with a major impact on hospital admissions and hospital costs and longer survival of the elderly.

Because of this, the prevention of accidents with elderly people has a direct impact on the costs of the health sector, making necessary the elaboration of public policies and public health preventive and promotional covering the subject. Primary Care, as the growing number of elderly people in the country, must adapt their guidelines for home visits to care for this public, if you want to achieve your goals and unblock other levels of care.

So it is essential that this aspect is perpetuated and propagated through training and Continuing Education - when it is implemented in the institutions - for professionals who work in home visits of primary care and home care are able to recognize and intervene in situations of risk of falls in the elderly. It is expected that arouse the interest of the community for the observation of these factors, since preventive measures of this order depends on the understanding and the desire to promote adaptations of those residing in the households. 


\section{REFERENCES}

1. Brasil. Instituto Brasileiro de Geografia e Estatística (IBGE). 2010 [Acesso em $10 \mathrm{abr}$ 2011].

Disponível

em: http: / / www.censo2010.ibge.gov.br/sinopse/índex.php?dados=12\&uf=00;

2. Organização Mundial da Saúde. Who Global Report on Falls Prevention in Older Age. 2007 [Acesso em dez 2010]. Disponível em: < http://www.who.int/ageing/publications/Falls_prevention7March>;

3. Gawryszewski VP. A importância das quedas no mesmo nível entre idosos no estado de são paulo. Rev Assoc Med Bras [Periódico na Internet]. 2010 [Acesso em 10 abr 2011]; 56(2):162-7. Disponível em http://www.scielo.br/pdf/ramb/v56n2/a13v56n2.pdf;

4. Söderqvist A, Ekström W, Ponzer $S$, Pettersson $H$, Cederholm $T$, Dalén N, Hedström $M$, Tidermark J. Prediction of mortality in elderly patients with hip fractures: a two-year prospective study of 1,944 patients. Gerontology [Periódico na Internet]. 2009 [Acesso em $10 \mathrm{abr} \quad$ 2010]; 55:496-504. Disponível em http: / / content.karger.com/ProdukteDB/produkte.asp?Doi=230587;

5. Menezes RL, Bachion MM. Estudo da presença de fatores de riscos intrínsecos para quedas em idosos institucionalizados. Cien saude coletiva [Periódico na Internet]. 2008 [Acesso em 10 2010]; 13(4):1209-218. Disponível em http: //www.scielosp.org/pdf/csc/v13n4/17.pdf;

6. Ribeiro AP, Souza ER, Atie S, Souza AC, Schilithz AO. A influência das quedas na qualidade de vida de idosos. Cien saude coletiva [Periódico na Internet]. 2008 [Acesso em 10 abr 2010]; 13(4):1265-273. Disponível em http://www.scielosp.org/pdf/csc/v13n4/23.pdf;

7. Goncalves LG, Vieira ST, Siqueira FV, Hallal PC. Prevalência de quedas em idosos asilados do município de Rio Grande, RS. Rev saude publica [Periódico na Internet]. 2008 [Acesso em 07 nov 2012]; 42(5):938-45. Disponível em http://www.scielo.br/pdf/rsp/v42n5/6845.pdf;

8. Lopes MCL, Violin MR, Lavagnoli AP, Marcon SS. Fatores desencadeantes de quedas no domicílio em uma comunidade de idosos. Cogitare Enferm [Periódico na Internet]. 2007 [Acesso em 07 nov 2012]; 12(4):472-77. Disponível em http://132.248.9.1:8991/hevila/Cogitareenfermagem/2007/vol12/no4/8.pdf;

9. Kalache A. O mundo envelhece: é imperativo criar um pacto de solidariedade social. Cien saude coletiva [Periódico na Internet]. 2008 [Acesso em 07 nov 2012]; 13(4):1107-11. Disponível em http://www.scielo.br/pdf/csc/v13n4/05.pdf;

10. Kelsey JL, Berry SD, Gray EP, Quach L, Nguyen USDT, Li W, Kiel DP, Lipsitz LA, Hannan MT. Indoor and outdoor falls in older adults are different: the maintenance of balance, independent living, intellect, and zest in the elderly of Boston study. J Am Geriatr Soc [Periódico na Internet]. 2010 [Acesso em 03 dez 2011]; 58:2135-41. Disponível em http://onlinelibrary.wiley.com/doi/10.1111/j.1532-5415.2010.03062.x/pdf; 
11. Silva EL, Menezes EM. Metodologia da pesquisa e elaboração de dissertação, 4 ed:UFSC. Florianópolis, 2005 [Acesso em 26 abr 2011]. Disponível em: <http://projetos.inf.ufsc.br/arquivos/Metodologia_de_pesquisa_e_elaboracao_de_teses_e_ dissertacoes_4ed.pdf;

12. Conselho Nacional de Saúde. Resolução n 196, de 10 de outubro de 1996. Brasília (DF): Conselho Nacional de Saúde; 2000;

13. Ioannidis G, Papaioannou A, Hopman WM, Danesh NA, Anastassiades T, Pickard L, Kennedy CC, Prior JC, Olszynski WP, Davison KS, Goltzman D, Thabane L, Gafni A, Papadimitropoulos EA, Brown JP, Josse RG, Hanley DA, Adachi JD. Relation between fractures and mortality: results from the Canadian Multicentre Osteoporosis Study. CMAJ [Periódico na Internet]. 2009 [Acesso em 07 nov 2012]; 181(5):265-71. Disponível em http: / /cmajopen.com/content/181/5/265.short;

14. Fabricio SCC, Rodrigues RAP, JUNIOR, MLC. Causas e conseqüências de quedas de idosos atendidos em hospital público. Rev saúde pública [Periódico na Internet]. 2004 [Acesso em 10 abr 2010]; 38(1):93-9. Disponível em http://www.scielosp.org/pdf/rsp/v38n1/18457.pdf; 15. Siqueira FV, Facchini LA, Piccini RX, Tomasi E, Thumé E, Silveira DS, Vieira V, Hallal PC. Prevalência de quedas em idosos e fatores associados. Rev Saude Publica [Periódico na Internet]. 2007 [Acesos em 07 nov 2012]; 41(5):749-56. Disponível em http://www.scielo.br/pdf/rsp/v41n5/6188.pdf;

16. Carvalho MP, Luckow ELT, Siqueira FV. Quedas e fatores associados em idosos institucionalizados no município de Pelotas (RS, Brasil). Cien saude coletiva [Periódico na Internet]. 2011 [Acesso em 07 nov 2012]; 16(6):2945-52. Disponível em http://www.scielo.br/pdf/csc/v16n6/32.pdf;

17. Antes DL, Contreira AR, Katzer JI, Corazza ST. Propriocepção de joelho em jovens e idosas praticantes de exercícios físicos. Fisioter Pesq [Periódico na Internet]. 2009 [Acesso 07 nov 2012]; 16(4):306-10. Disponível em http://www.revistasusp.sibi.usp.br/pdf/fpusp/v16n4/04.pdf;

18. Baptista RR, Vaz MA. Arquitetura muscular e envelhecimento: adaptação funcional e aspectos clínicos: revisão da literatura. Fisioter Pesq [Periódico na Internet]. 2009 [Acesso

07 nov 2012]; 16(4):368-73. Disponivel em http: //www.revistasusp.sibi.usp.br/pdf/fpusp/v16n4/15.pdf;

19. Guimaraes JMN, Farinatti PTV. Análise descritiva de variáveis teoricamente associadas ao risco de quedas em mulheres idosas. Rev Bras Med Esporte [Periódico na Internet]. 2005 [Acesso 07 nov 2012]; 11(5):299-305. Disponível em http://www.scielo.br/pdf/rbme/v11n5/27593.pdf;

20. Gai J, Gomes L, Nobrega OT, Rodrigues MP. Fatores associados a quedas em mulheres idosas residentes na comunidade. Rev Assoc Med Bras [Periódico na Internet]. 2010 [Acesso 07 nov 2012]; 56(3):327-32. Disponível em http://www.scielo.br/pdf/ramb/v56n3/v56n3a19.pdf;

21. Ferreira DCO, Yoshitome AY. Prevalência e caraterísticas das quedas de idosos institucionalizados. Rev bras enferm [Periódico na Internet]. 2010 [Acesso 07 nov 2012]; 63(6):991-7. Disponível em http://www.scielo.br/pdf/reben/v63n6/19.pdf;

22. Alvares LM, Lima RC, Silva RA. Ocorrência de quedas em idosos residentes em instituições de longa permanência em Pelotas, Rio Grande do Sul, Brasil. Cad Saude Publica 
[Periódico na Internet]. 2010 [Acesso 07 nov 2012]; 26(1):31-40. Disponível em http://www.scielosp.org/pdf/csp/v26n1/04.pdf;

23. Marin MJS, Amaral FS, Martins IB, Bertassi VC. Identificando os fatores relacionados ao diagnóstico de enfermagem "risco de quedas" entre idosos. Rev bras enferm [Periódico na Internet]. 2004 [Acesso 07 nov 2012]; 57(5):560-4. Disponível em http://www.scielo.br/pdf/reben/v57n5/a09v57n5.pdf; 